\title{
kryminału z historią, czyli uwag kilka o kryminałach retro Konrada T. Lewandowskiego
}

Na przełomie XX i XXI wieku spotykamy się ze swoistą restytucją historii w różnych nurtach i odmianach gatunkowych literatury. Jednym $\mathrm{z}$ autorów, którego twórczość stanowi potwierdzenie tego przekonania, jest Konrad T. Lewandowski. Pisarz, publicysta, dziennikarz - autor wszechstronny: zaczynający od literatury fantasy, swobodnie operujący science-fiction, piszący powieści kryminalne retro, powieści historyczno-przygodowe, w końcu zaskakujący steampukową powieścią o powstaniu styczniowym. W wielu z nich tłem wydarzeń lub osią konstrukcji fabularnej, tematem, ale i problemem, przedmiotem popularyzacji, lecz częściej prowokacji jest HISTORIA.

Objętość artykułu uniemożliwia całościowe, monograficzne omówienie prozy Lewandowskiego $\mathrm{z}$ historią $\mathrm{w}$ tle. $\mathrm{W}$ niniejszym tekście skupię się zatem na analizie sposobów „użytkowania historii” w serii kryminałów retro tego autora powstałej na zamówienie Wydawnictwa Dolnośląskiego'. Wybór ten znajduje podwójne uzasadnienie. Po pierwsze: kryminał retro jest interesującym przykładem dokonującego się po śmierci wielkich narracji

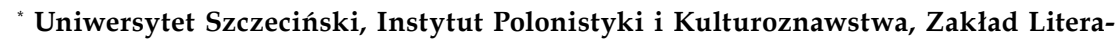
tury Polskiej XX i XXI wieku, e-mail: ewa.tierling@usz.edu.pl.

${ }^{1}$ Podaję chronologicznie listę tytułów serii wraz z oznaczeniami literowymi, którymi sygnuję odwołania i cytacje z poszczególnych książek K. T. Lewandowskiego: Magnetyzer. Powieść kryminalna retro, Poznań 2007 - (M); Bogini z labradoru. Powieść kryminalna, Wrocław 2007 - (B); Elektryczne perty. Powieść kryminalna retro, Wrocław 2007 - (E); Perkalowy dybuk. Powieść kryminalna retro, Wrocław 2009; Ślaskie dziękczynienie. Powieść kryminalna retro, Wrocław 2010 - (S). O okolicznościach i szczegółach tego zamówienia mówi sam Lewandowski w jednym z wywiadów - zob. K. T. Lewandowski, Rzemieślnik metafizyk, rozm. P. Dunin-Wąsowicz, [online] http://ksiazki.onet.pl/rzemneslnik-metafizyk/x078z (dostęp: 25.08.2016).

Określenie „użytkowanie historii" nawiązuje do tytułu książki znanego historyka Marcina Kuli - zob. M. Kula, Krótki raport o użytkowaniu historii, Warszawa 2004. 
powrotu historii do literatury niejako „kuchennymi drzwiami”. Historia wchodzi bowiem $\mathrm{w}$ małżeństwo $\mathrm{z}$ jednym $\mathrm{z}$ gatunków przynależnych do literatury popularnej, dla wielu do niedawna niegodnych, by zajmowała się nim poważna historia literatury². Badanie skutków tego mezaliansu może okazać się bardzo zajmujące; także ważne ze względu na to, iż lista autorów piszących kryminały retro ciągle się wydłuża. Po drugie, Lewandowski staje się coraz bardziej rozpoznawalny jako autor historii alternatywnych ${ }^{3}$. Zamierzoną przeze mnie w kolejnym artykule interpretację jego dzieł przynależnych do tego nurtu chciałabym poprzedzić zbadaniem, w jaki sposób w serii przygód nadkomisarza Drwęckiego realizowane są warianty gry z czytelnikiem (i historią), które ulegają pełniejszemu rozwinięciu w kolejnych eksperymentach $\mathrm{z}$ historyczną kontrfaktycznością w innych dziełach tego autora. Interpretacja kryminałów retro Lewandowskiego to wędrówka przez różne odmiany historycznego prawdopodobieństwa, od prawdy historycznej do „historii niebyłej”" To także konieczność postawienia pytania, co z takiego operowania historią byłą i niebyłą wynika dla dalszego rozwoju prozy historycznej i dla jej odbiorcy u progu XXI wieku.

\section{Kryminał retro - co to takiego?}

Jeżeli powieść kryminalna jest gatunkiem zmąconym, to jej wersja retro stanowi tego zmącenia interesującą egzemplifikację ${ }^{5}$. Kontaminacja narracji o historii z gatunkiem o nieostrych granicach, a wielu inwariantach, jakim jest powieść kryminalna, przynosi obu połączonym dyskursom liczne korzyści. Na początek przyjrzeć się należy, co zyskał kryminał poprzez „upadek w czas”, jak metaforycznie nazwał to Mariusz Czubaj, autor kryminałów i ich badacz dokonujący analizy powieści kryminalnej jako świadectwa antropologicznego ${ }^{6}$. Niewątpliwie zanurzenie w historię, a także w „konkret, codzienność, i kulturowe realia” zwiększa prawdopodobieństwo kryminalnej intrygi ${ }^{7}$. To w miejscu często znanym czytelnikowi

${ }^{2}$ Przekonanie to werbalizuję per analogiam do mego zdania o popularności gatunków do tej pory „niegodnych poważnej historii akademickiej” sformułowanego w moim artykule Powstanie styczniowe, którego nie było, czyli historia alternatywna w powieści Adama Przechrzty "Gambit Wielopolskiego", [w:] Dyskurs powstańczy w kulturze polskiej, red D. Dąbrowska, Szczecin 2015.

${ }^{3} \mathrm{~W}$ wymienionym $\mathrm{w}$ przypisie 3 artykule podjęłam próbę uporządkowania taksonomii „historii niebyłej”/„historii alternatywnej” w polskiej historiografii i literaturze pięknej. Tam też zamieściłam przyjmowaną przeze mnie definicję historii alternatywnej autorstwa Tomasza Węcławiaka. Zob. także: T. Węcławiak, Historia historii nierówna - kilka uwag o definicji historii alternatywnej, „Podteksty. Czasopismo kulturalno-naukowe” 2007, nr 4 [online], http://podteksty.amu.edu.pl/podteksty/?action=dynamic\&nr=11\&dzial=4\&id=254 (dostęp: 05.08.2016).

${ }^{4}$ Określenie "historia niebyła” pochodzi od tytułu książki Alexandra Demandta - zob. A. Dermandt, Historia niebyta: Co by było gdyby...?, przeł. M. Skalska, Warszawa 1999.

${ }^{5} \mathrm{O}$ kryminale jako gatunku zmąconym pisał Mariusz Czubaj, wymieniając kilka typologii modeli powieści kryminalnej (Carla D. Malmgrena, Otto Penzlera). Rzecz znamienna, że "kryminał retro" nie został uwzględniony jako model w żadnym podziale ani podany jako przykład wariantu modelu gatunkowego. Zob. M. Czubaj, Etnolog w Mieście Grzechu. Powieść kryminalna jako świadectwo antropologiczne, Gdańsk 2010, s. 28-42.

${ }^{6}$ Tamże, s. 12.

${ }^{7}$ Tamże, s. 13 i nn. 
z autopsji i w określonym historycznie czasie rozgrywają się prezentowane wydarzenia. Kwestia ukonkretnionej czasoprzestrzeni zyskuje dodatkowe znaczenie, jest nacechowana aksjologicznie:

Przepis na kryminał retro pozornie jest prosty: czas - przeszłość mniej lub bardziej odległa, najlepiej międzywojnie, miejsce - miasto (preferowane multikulturowe), bohater - wyrazisty, niepokorny, raczejá la Marlowe niż Poirot. I oczywiście interesująca zagadka, najlepiej mroczna, z większą lub mniejszą nutką dekadencji, podważająca mit o starych dobrych (czytaj: spokojnych) czasach albo, przeciwnie, budząca tęsknotę i zazdrość, że kiedyś, wszystko, łącznie ze zbrodnią, było lepsze ${ }^{8}$.

Autorka przywołanej definicji, Katarzyna Wajda uważa, że „motyw czasu i nostalgii jest kluczowy dla nurtu”, a termin retro "długo funkcjonował jako synonim międzywojnia, świata podwójnie utraconego nie tylko przez naturalny upływ czasu, ale też zmiany historyczne”, gdyż „PRL zerwał więź z II RP”. Dalej autorka dodaje: „Kryminały retro to również popkulturowa forma odzyskania tej utraconej więzi, odnalezienia »małej ojczyzny« i opowiedzenia o niej w atrakcyjny sposób”9.

\section{Z nadkomisarzem Drwęckim przez Dwudziestolecie ${ }^{10}$}

Należałoby w tym momencie zilustrować wymienione wyżej, a związane z zachowaniem konwencji realistycznej w "kryminale retro", wymiary obecności historii $\mathrm{w}$ powieściach kryminalnych Lewandowskiego. Z nader długiej listy przykładów konstruowania historycznie ukonkretnionej czasoprzestrzeni oraz kreowania realiów (i klimatu) prezentowanej epoki wybieram najważniejsze. Autor wykazuje się dobrą znajomością topografii i historycznych realiów Warszawy, Łodzi, Poznania czy też Śląska - miast i obszarów wielokulturowych, o bogatej i skomplikowanej historii, które czyni miejscem akcji serii przygód nadkomisarza Drwęckiego. Niekoniecznie opisuje je ze szczególnym sentymentem i respektem wobec "starych dobrych czasów". Na przykład w Poznaniu bohater nie wsiada do tramwaju nr 5, gdyż wagony tegoż, jadąc wokół placu Nowomiejskiego w zbyt ciasnych zakrętach, często wykolejają się (E, 109-110) ${ }^{11}$.

${ }^{8}$ K. Wajda, Śladem retrozbrodni, [online] http://www.dwutygodnik.com/artykul/3820-sladem-retrozbrodni.html (dostęp: 25.08.2016).

${ }^{9}$ Tamże.

${ }^{10}$ Śródtytuł nawiązuje do sloganu zaproponowanego przez Katarzynę Wajdę „z komisarzem Drwęckim przez międzywojnie - ludzie, miejsca wydarzenia" (tamże). Jerzy Drwęcki w pewnym momencie awansuje i zostaje nadkomisarzem. Od drugiego tomu serii występuje już jako nadkomisarz. Dla klarowności wywodu niezależnie do drogi awansu bohatera także przy odwoływaniu do Magnetyzera, pierwszej książki z serii, posługuję się późniejszym stopniem policjanta.

${ }^{11}$ Przykłady można by mnożyć. Opisy „polskiego Manchesteru”, czyli Łodzi, przedstawione w Perkalowym dybuku udowadniają raczej, jak bardzo nie jest to ziemia obiecana - ukazują przypadkowość i cywilizacyjną niższość tej aglomeracji w stosunku do Warszawy. Ta nie podlega bynajmniej bezrefleksyjnej idealizacji. Pałac Kronenberga powstały jeszcze w XIX wieku nie świadczy o pięknie międzywojennej stolicy: „,[...] dach projektował chyba 
Lewandowski odtwarza koloryt lokalny poszczególnych miejsc, gdy każe wziąć udział Drwęckiemu w szlachtowaniu wieprza na Śląsku, ale też wtedy, kiedy tenże policjant, uczestnicząc w życiu śląskiej rodziny, codziennie je na obiad eintopf oraz zajmuje się edukacją małego Walika (Ś). Słyszymy w Ślaskim dziękczynieniu śląską gwarę, a w Bogini z labradoru pobrzmiewa lwowskie bałakanie Gryfka, kolegi Drwęckiego z czasu walk o Lwów. Wiele o epoce mówi Powszechna Wystawa Krajowa w Poznaniu, która została unaoczniona w Elektrycznych perłach.

Główny bohater spotyka na swej drodze postacie historyczne, między innymi Józefa Piłsudskiego, Bolesława Wieniawę-Długoszowskiego, Wojciecha Korfantego. Status głównego bohatera uzasadnia jego przebywanie w różnych miejscach i środowiskach. Dlatego też odbiorca powieści poznaje nie tylko elity polityczne czy kulturalne międzywojnia, ale i gangstera Tatę Tasiemkę oraz prawa rządzące na Karcelaku, a także dowie się, czym była przestępcza dintojra.

Postacie historyczne swobodnie przemieszane są z fikcyjnymi. Pojawienie się na kartach powieści wujaszka Hiacyntusa i jego przyjaciół uzmysławia czytelnikowi, jak wielki był kult weteranów powstania styczniowego w Dwudziestoleciu ${ }^{12}$.

Można powiedzieć, że im większa kompetencja kulturowa - zarówno znajomość historii (faktów, osób, realiów historycznych), jak i erudycja literacka odbiorcy, tym większa smakowitość literackiej zabawy historią i konwencją gatunkową. Drwęcki bowiem jest stałym bywalcem Ziemiańskiej. $\mathrm{Tu}$ debatuje z Franciszkiem (Francem) Fiszerem, rozmawia z Tadeuszem Boyem-Żeleńskim. Czytelnik wraz z bohaterami poznaje Juliana Tuwima i Antoniego Słonimskiego. Autor zmierza traktem literackiego mitu i anegdoty. W Elektrycznych perłach sięgnięcie do legendy literackiej Przybyszewskiego staje się kluczem do kryminalnej zagadki i prowokuje czytelnika do postawienia pytania o możliwe, prawdopodobne, acz nieudokumentowane epizody i wątki biografii "smutnego szatana” epoki Młodej Polski. Sam Lewandowski deklarował w jednym z wywiadów: „Tak jak metafizykę Fiszera odtwarzam polskie elity pogrzebane w Palmirach i Katyniu"13.

Tu, obok nadawania historycznego i realistycznego prawdopodobieństwa kreowanej intrydze, ujawnia się druga, przynajmniej potencjalnie możliwa, funkcja kryminału retro, związana z istnieniem podwójnego adresata tego podgatunku. Obok kompetentnego kulturowo czytelnika, drugim potencjalnym odbiorcą kryminału retro jest odbiorca literatury i kultury popularnej, który być może już nie czytuje powieści Henryka Sienkiewicza, nie wie nawet, kim była Zofia Kossak. Poprzez lekturę kryminału retro „nasiąka on historią", chwyta historycznego bakcyla, obcując nie tyleż nawet $\mathrm{z}$ faktografią, ile z klimatem lat dwudziestych i trzydziestych XX wieku, klimatem

pijany grabarz albo była to kryptoreklama zakładu pogrzebowego, stworzona z kombinacji pięciu trumien, postawionych do góry nogami i powtykanych jedna w drugą. Dziwne, że ktoś godził się mieszkać pod takim dachem, a jeszcze dziwniejsze, że owo dadaistyczne memento mori stało dokładnie przed frontem Zachęty" (B, 137). Lewandowski w opisie mocno przesadził, choć styl eklektyczny budowli niekoniecznie mógł się mu podobać.

${ }^{12}$ Postaci tej autor nadał nazwisko swego dziadka, ułana $1920 \mathrm{r}$.

${ }^{13}$ K.T. Lewandowski, Rzemieślnik metafizyk... 
pogrzebanych elit. Historia roztopiona w poetyce kryminału jest być może jedyną historią, z którą odbiorca popkultury obcuje. Nawet jeżeli popularyzacja historii okazuje się jednym z celów „użytkowania historii” w kryminale retro Lewandowskiego, nie jest to cel jedyny i chyba nie najważniejszy.

$Z$ jakim rodzajem odtwarzania elit mamy do czynienia, skoro autor pozwala sobie na stworzenie w Bogini z labradoru alternatywnego życiorysu młodego Witolda Gombrowicza, który na zamówienie elity warszawskiej zajmującej się okultyzmem (właściwie okultystyczno-patriotycznej sekty) pisze "dramat okultystyczny, celem upowszechnienia idei teozoficznych"? Z literatury żyć nie zamierza, lecz owe dzieło tworzy, przewidując zresztą literacką kompromitację. Jak tłumaczy Drwęckiemu:

Za rok skończę studia ekonomiczne w Paryżu [...]. Potem zamierzam rozpocząć w Warszawie aplikację adwokacką. A nasza gospodyni, jak pan pewnie wie, może w tych sprawach równie wiele ułatwić, co utrudnić (B, 76).

Jakby tego było mało, za sprawę koniunkturalnego uwikłania młodego twórcy odpowiada Witkacy, który postanowił stworzyć z Gombrowicza wielkiego pisarza, a potem sobie „w łeb palnąć", co wyjaśnia tyleż nadkomisarzowi, co odbiorcy powieści (B, 108). Czemu służy najwyraźniej karkołomny żart literacki, adresowany $\mathrm{w}$ tym przypadku do odbiorcy na tyle dobrze znającego życie i twórczość obu pisarzy, by móc dostrzec, jak daleko posunął się autor operujący na biografii przede wszystkim Gombrowicza?

Nie podważając powyższej deklaracji pisarza dotyczącej literackiej kreacji elit pogrzebanych w Katyniu, stwierdzić muszę, że nie walor edukacyjny - popularyzacji historii, a nawet nie ludyczny wybija się na plan pierwszy, gdy Lewandowski pokazuje odbiorcy inną możliwość czyjegoś życiorysu, odmiennego od utrwalonego $\mathrm{w}$ annałach przebiegu historycznego wydarzenia, albo też próbuje postawić pytanie o „drugie dno", ukazać palimpsestowość historycznych wydarzeń. Nie bez powodu ulubioną postacią historyczną z międzywojnia jest dla Lewandowskiego Franciszek Fiszer, filozof i metafizyk, a system logiki trójwartościowej Jana Łukasiewicza staje się podstawą nie tylko prowadzonych przez Drwęckiego śledztw, ale kluczem do rozumienia rzeczywistości także tej pozaliterackiej. Należałoby w tym miejscu odesłać do dwóch fragmentów z Magnetyzera, które mogą posłużyć jako wykładnia zarówno rozważań o historii, jak i eksperymentów na niej dokonywanych przez Lewandowskiego również w tekstach spoza kryminalnej serii.

Nadkomisarz Drwęcki to niedoszły logik, student Jana Łukasiewicza, do którego policjant w Magnetyzerze przychodzi po radę, co staje się okazją do przywołania teorii profesora:

[...] Czym wobec tego mogę służyć?

- Tym, co pan profesor osobiście był łaskaw odkryć. Trzecią wartością logiczną. Uczył nas pan, że w logice oprócz prawdy i fałszu jest jeszcze wartość trzecia, czyli możliwość. Zatem jaką możliwość pan profesor tu dostrzega? (M, 27). 
Zaś Fiszer, kwestionując sensowność „igrania z czasem” w Torpedzie czasu Słonimskiego i polemizując z teorią Einsteina, stwierdza: „Zatem »teraz« istnieje bezwzględnie! To przyszłość i przeszłość są niepewne i niekonieczne" (M, 55). Przeszłość-historia-dzieje poza prawdą i fałszem faktografii okazują się domeną możliwości, prawdopodobieństwa, a domniemania na ich temat niepewne. Tak otwiera się szerokie spektrum gry z historią prowadzonej przez Lewandowskiego.

\section{Legenda historyczna i jej dekonstrukcja}

W kryminalnej serii pisarz w formie dokonywanych przez bohaterów retrospekcji przywołuje ważne wydarzenia historyczne z historii Polski. Wprowadzenie ich na karty powieści w różnoraki sposób służy przypomnieniu faktów i osób, ale w jeszcze większym stopniu ma na celu rozprawienie się z legendą historyczną. Dla klarowności wywodu wyszczególnię w punktach trzy sposoby/trzy stopnie dokonywanego przez Lewandowskiego demontażu historycznej legendy.

\section{Wariant A.}

Opowieść o wydarzeniach. Legenda zasadniczo pozostaje w mocy, ale bohaterowie są zmęczeni

W Bogini z labradoru ukazana zostaje kombatancka przeszłość nadkomisarza Drwęckiego. Jerzy razem ze swoim frontowym kolegą Gryfkiem wspomina ich walki z Ukraińcami o Lwów, a następnie "spowiada się" żonie ze swojej wojennej przeszłości 1920 roku. Fikcyjni bohaterowie wprowadzeni zostają na plan historycznych wydarzeń, przez co ich losy zyskują walor powieściowego prawdopodobieństwa. Ich osobiste historie, mieszczące się w ramach dziejowej faktografii i legendy, dla odbiorcy utworu - paradoksalnie - stanowią potwierdzenie opowiadanej makrohistorii. Ani faktograficzna historia, ani legenda nie zostają definitywnie podważone. Opisy heroicznej walki młodzieży we Lwowie w 1918 roku należą do ciekawszych epizodów powieści; zyskują znaczenie edukacyjne, gdyż przedstawiają ciągle nie dość znane wydarzenia historyczne. Jeśli można mówić o demitologizacji, to ma ona ograniczony charakter. Narracja o Orlętach Lwowskich jawi się jako próba unaocznienia tego, co zdaniem bohatera było zarazem piękne i straszne.

Przedstawienie bohaterskich zmagań na Górze Stracenia w 1918 roku zostaje niejako zrównoważone podsumowaniem pierwszych godzin walk w mieście: „Tak z początku wyglądała ta legendarna obrona Lwowa prawie wszędzie - kompletny chaos, patriotyczne szaleństwo i wariacka improwizacja" (B, 68). W powieści rozmaite są losy poszczególnych uczestników wojny z Ukraińcami. Pyziabułcia walcząca u boku kolegów stanie się później nieco śmiesznym wcieleniem polskiej matrony, matki-Polki, pani dyrektorowej Zasławskiej praktykującej okultyzm, a jednak budzącej sympatię właśnie ze względu na wojenną przeszłość. Jednocześnie opowiedziana 
historia Mientkiego (nie bez powodu nazwanego przez towarzysza broni sukinsynem i ścierwem) pokazuje, że nie wszyscy po „polskiej stronie” byli bohaterami.

Przypomnienie legendy Orląt Lwowskich jest jedynie wstępem do skontrastowania ich walk z o wiele okrutniejszą wojną 1920 roku. Refleksje na jej temat pozwalają domknąć dokonywaną w powieści analizę problemu wojennej traumy. Nadkomisarz tłumaczący żonie różnicę między obiema wojnami staje się mentorem także wobec czytelnika. Odgrywa rolę protagonisty utworu, który w dostępnej formie przypomina, że zwycięstwo 1920 roku miało również swoje koszty moralne. Nieco kontrowersyjna w swojej prostocie lekcja historii bardziej może przemówić do słabo znającego historię czytelnika niż jej wykładnia z podręcznika szkolnego. Rosyjski i zarazem bolszewicki nihilizm zyskują zdroworozsądkowe wytłumaczenie, dalekie od naukowej filozoficznej i historycznej analizy złożoności zjawiska.

Wojna ukraińska była „ludzka”, wojna bolszewicka „nieludzka”. Pierwsza była o ziemie i miejsca do życia.

[W takiej wojnie - E.T-Ś. ] Rozstrzyga odwaga i żelazo, a zwycięzca decyduje o wszystkim, łącznie z racją historyczną i moralną. Natomiast wojna bolszewicka była o ideę, a idee z człowieczeństwem nie mają już nic wspólnego. Idee, jak tylko dotkną ziemi, zaraz ropieją i wyradzają się w tępą nienawiść ${ }^{14}$. [...] wzięli takiego »mużyka« znad Wołgi czy gdzieś spod Uralu i powiedzieli mu, że nie ma już Boga ani cara. Co jest zamiast nich, niby mówili, ale nie zrozumiał. W każdym razie zrozumiał tyle, że to polskie pany wszystkiemu winne. Tak i mścił się mużyk na panach za to, że nie ma Boga, ani cara, ani żarcia, a jak niczego nie ma, to po co żyć i dawać żyć innym? Taki nihilizm jest strasznie zaraźliwy (B, 120).

Pojawiająca się $\mathrm{w}$ powieści zaledwie dwadzieścia stron później scena spotkania Jerzego twarzą $\mathrm{w}$ twarz $\mathrm{z}$ wrogiem i zamordowania go przez Drwęckiego z niebywałą zaciekłością stanowi dowód takowego zakażenia nihilizmem i nienawiścią, zakażenia, które było „gorsze od hiszpanki powikłanej raną od bagnetu" $(B, 140)$. Mara ukraińskiej sanitariuszki zastrzelonej przez Drwęckiego powracająca w jego koszmarach sennych, zabicie pierwszego Ukraińca, powodujące, że przyszły pracownik policji kryminalnej nie może spokojnie patrzeć na trupy, przez co umykają mu istotne szczegóły śledztwa, to egzempla wojennej traumy nabytej w bohaterskiej walce 1918 roku. Traumy, która zostaje pogłębiona w 1920 roku zakażeniem przyjemnością mordowania: „Do tej pory jest mi głupio, gdy muszę aresztować lub przesłuchać jakiegoś szalonego zabójcę. Nie jestem od niego lepszy" (B, 140)

Wojna jest okrutna i zostawia blizny nie tylko na ciele, udział w niej podlega moralnej ocenie, a relacja o niej nie może zostać pozbawiona etycznego wymiaru - zdaje się zupełnie serio przypominać znaną prawdę Lewandowski. Pisarz w opowieści o historii idzie jednak dalej. Powrót do

\footnotetext{
${ }^{14}$ Znów tylko czytelnik erudyta uchwyci literacką aluzję od „ideału sięgającego bruku”.

${ }^{15} \mathrm{~W}$ dalszej części dialogu z żoną nadkomisarz jednak dostrzega różnicę. Rozmowa Drwęckich może drażnić nachalnym dydaktyzmem.
} 
trzeciego wymiaru logiki, czyli możliwości, w narracji o historii potrafi odwrócić powszechnie znaną aksjologiczną kwantyfikację historycznych osób i wydarzeń. Pokazuje też, że historia, nie zawsze sprowadzona do logicznych wartości prawdy lub fałszu, podlega etycznemu wartościowaniu w zależności od tego, jak zostaje opowiedziana. Lewandowski prowokuje odbiorców, szczególnie tych znających dzieje powstań śląskich, kolejnym wariantem opowiadania historii.

\section{Wariant B.}

\section{Opowieść o wydarzeniach. Fakty zostają, umiera legenda}

W Śląskim dziękczynieniu świniobicie, którego uczestnikiem jest Drwęcki, staje się okazją do rozmowy policjanta z szeregowymi uczestnikami trzeciego powstania śląskiego ${ }^{16}$. Prezentowana relacja historycznych wydarzeń zostaje ujęta w rodzaj semantycznej klamry - domniemania, iż to wersja historii nie dla harcerskich uszu: „Ale harcerzom pan nadkomisarz nie powtórzy?" $(S$, 97), „Tylko harcerzom ani mru-mru, boby nam karlusy jeszcze strachu przed Niemcami nabrali!" (Ś, 100). Czytelnik ma bowiem dowiedzieć się, jak wyglądał naprawdę „odwrót na z góry upatrzone pozycje” $(S, 97)$ w rejonie Góry Świętej Anny. Owo powieściowe „naprawdę” jest w rzeczywistości jednoznaczną interpretacją wydarzeń dokonaną przez autora powieści, podważającą legendę o bohaterskiej obronie góry przez Polaków ${ }^{17}$. Interpretacja ta opiera się na zawieszeniu wartościowania historii $\mathrm{w}$ kategorii prawdy i fałszu i na wprowadzeniu trzeciej wartości logicznej: skoro bitwa militarnie nie została rozstrzygnięta, a nastąpił w jej trakcie polski odwrót, to wbrew opowieści o polskim bohaterstwie "prawdopodobnie" wyglądał on tak, jak zostaje to ukazane $w$ powieści. Jednocześnie znaczenie bitwy dla losów powstania i jej symboliczny wymiar w historii Polski nie zostają podważone. W tym sensie fakty pozostają faktami, a umiera legenda.

Zdaniem sierżanta Kruka na mapach w gazetach i „książkach od historii” $(S, 98)$ „linie frontu są tak grubymi krechami wymalowane, że trudno poznać co i jak. [...] Pierony wszystko tak pozamazywali, że zdaje się jakby nic wielkiego się tam nie stało" (Ś, 98). Kruk i Gajdak dopowiadają zatem szczegóły zamazanej na mapach historii, tej historii odbiegającej od oficjalnej wersji. Po opisie dramatycznej ucieczki przed Niemcami obaj kombatanci podsumowują:

- [...] Cały ten dzień i następny to był jeden wielki pogrom i chaos. Niemcy gonili za nami, byli przed nami, wokół nas, wszędzie.

${ }^{16} \mathrm{~W}$ przypadku "przepisywania historii” jest to typowe oddanie głosu zwykłym ludziom, szeregowcom, a nie politykom czy generałom, wprowadzenie do narracji o historii perspektywy ",oddolnej”, „nieoficjalnej” niekoniecznie w utrwalonej podręcznikach.

${ }^{17}$ Opis bitwy przedstawia m.in. Wojciech Kempa, Bitwa w rejonie Góry św. Anny [online] http://www.siemianowice.pl/aktualnosci/historia-i-oswiata/bitwa-w-rejonie-gory-sw-anny.2203/ (dostęp: 31.08.2016). 
- I jak nas zobaczyli, krzyczeli: Schlachtenpolen! - mruknął Kruk. - Dziś my tutaj sobie na świniobiciu siedzimy, a wtedy Niemcy zrobili sobie regularne polakobicie... (Ś, 98).

Potem Gajdak, kończąc demontowanie kolejnych elementów składowych tejże legendy, stwierdza: „Niemcy sami się zatrzymali. [...] Mieli nas ze spuszczonymi spodniami i nie sprali rzyci. Do tej pory nie wiem czemu?" (Ś, 99). Ślązacy wyjaśniają zarówno nadkomisarzowi, jak i czytelnikowi istotę przewagi Niemców nad nimi. Są też przekonani, że uratował ich Wojciech Korfanty, który jakieś czary chyba odprawił.

\title{
Wariant C.
}

\section{Opowieść o bohaterze? Demontaż pozytywnej legendy}

Kreacja osoby Wojciecha Korfantego w Śląskim dziękczynieniu jest przykładem najbardziej radykalnego i najbardziej kontrowersyjnego przeistoczenia faktografii i legendy postaci historycznej. Pozytywna legenda polityka w powieści Lewandowskiego ulega wzięciu w nawias poprzez wmontowanie jej w ramę narracji stanowiącej formę "czarnego pijaru”.

Wedle historycznych źródeł i opracowań, ujmując kwestię w największym skrócie, Korfanty opowiadający się za polskością Śląska, ale przeciwny powstaniu, w chwili gdy powstanie okazało się koniecznością, stanął na jego czele. Widział w nim jedynie zbrojną manifestację Ślązaków wobec Komisji Międzysojuszniczej, która miała dokonać podziału terenu plebiscytowego między Polskę a Niemcy. Dlatego też dążył do zakończenia powstania w chwili najdogodniejszej dla procesu ustanowienia granic, zanim doszłoby do klęski powstania lub rozpętałaby się wojna polsko-niemiecka ${ }^{18}$. W powieści polityk, przekonany o przewadze Niemców oraz niechętny niepotrzebnemu rozlewowi krwi ${ }^{19}$, wyjaśnia mechanizm działania owych „czarów” po bitwie w rejonie Góry Świętej Anny, o których mówili byli powstańcy. Poniższa wypowiedź potwierdza odnotowywany przez biografa demagogiczny talent Korfantego:

\begin{abstract}
Pozwoliłem Niemcom paść ofiarą własnej propagandy. Oni stale krzyczeli, że nasi powstańcy to przebrane wojsko polskie, więc ja niby to oficjalnie dementując te zarzuty, jednocześnie po cichu robiłem wszystko, żeby ich w tych podejrzeniach utwierdzić. [...] Wojsko polskie, które rok wcześniej brawurowo rozprawiło się z bolszewikami pod Warszawą, nie mogło przecież zostać pokonane tak łatwo... (Ś, 107).
\end{abstract}

Istotniejsza dla zrozumienia mechanizmu kreowania postaci jest dłuższa wypowiedź bohatera, który wyjaśnia powody tak prowadzonej polityki. Nie miejsce tu na przytaczanie całości wypowiedzi Korfantego. Istotne jest natomiast jej zakończenie. Pod słowami:

\footnotetext{
${ }^{18}$ Szerzej na ten temat zob. np.: J. F. Lewandowski, Wojciech Korfanty, Warszawa 2013.

${ }^{19}$ To poglądy także „historycznego" Korfantego.
} 
W żadnym wypadku wojna nie może być walką dla samej walki, zaspokojeniem emocjonalnej potrzeby uwolnienia gniewu, bohaterskiego spełnienia, ani jakąś grą o punkty honoru. Wiedzą to wszystkie europejskie narody z wyjątkiem Polaków (Ś, 106)

podpisałoby się zapewne wielu współczesnych przeciwników nurtu insurekcyjnego w historii Polski. Retoryka tej wypowiedzi jest jednakże demagogiczna - bazuje na skrótach myślowych, emocjach, trudno z nią merytorycznie dyskutować, a przecież obrońcy powstań nigdy zapewne nie twierdziliby, że wybuchały one z wymienionych powodów. Demagogia to Korfantego czy Lewandowskiego? Niezależnie od historycznej adekwatności wypowiedzi, lapidarność przekazu i jego kontekst powodują, że zdania takowe jak slogan reklamowy łatwo wpadają w ucho i mogą stać się powtarzanymi aforyzmami ${ }^{20}$.

Pozornie wydawałoby się, iż pisarz powiela pozytywną legendę znanego polityka. Jak zauważyłam wyżej, jest jednak inaczej. W Śląskim dziękczynieniu, biorąc pod uwagę luki w życiorysie oraz nieliczne przesłanki dotyczące osobowości postaci historycznej - $\mathrm{w}$ tym próby zdyskredytowania polityka jeszcze w Dwudziestoleciu, w końcu negatywne opinie o nim -Lewandowski dekonstruuje jego pozytywną legendę. Mogą w nią wierzyć jedynie szeregowi uczestnicy historii i - co pokazuje utwór - gotowi są dla niej wiele poświecić, nawet stając w obliczu przeczących jej faktów.

Powieściowy Korfanty to nie tylko sprytny polityk, ale defraudant dotacji przeznaczonych na polskie powstanie. O tym, że nie jest to tylko oskarżenie przeciwników politycznych, przekonać ma odbiorcę afera gospodarczo-finansowa, której śląski przywódca okazuje się w powieści głównym bohaterem. Afera staje się osią konstrukcyjną kryminalnego śledztwa, ponieważ towarzyszą jej ofiary w ludziach. Zabójstwo współpracownika Korfantego, jedynego świadka mogącego oskarżyć polityka przed sądem, zamyka możliwość rozliczenia cynicznego przywódcy, który w trakcie rozmowy $\mathrm{w}$ restauracji przyznaje:

Nie po to się idzie do polityki, aby cierpieć za miliony ani by się poświęcać i umartwiać [...]. Polityk jest od gromadzenia władzy, pieniędzy i ludzi po to, aby móc nimi dysponować według swego uznania, czyli zwykle po to, aby pozyskać jeszcze więcej władzy, pieniędzy i ludzi. [...] Najrozsądniejsza rada to dać ludowi symboliczne igrzyska, a wszystkie namacalne konkrety wziąć dla siebie (Ś, 108-109).

Jak podaje Jan F. Lewandowski, autor biografii Korfantego: „Jest faktem, że w akcji politycznej Korfanty nie przebierał w środkach, jak to zauważali i Niemcy, i jego współpracownicy"21. Na przykład czechosłowacki konsul w Opolu „raportował do Pragi” między innymi, iż Korfanty „[...] opanował wszelkie metody bezwzględnej walki, i dla niego wszystkie środki są

\footnotetext{
${ }^{20}$ Podobnie powtarzanym aforyzmem może stać się cytowane zdanie Drwęckiego o ropieniu idei po zetknięciu ich z ziemią.

${ }^{21}$ J. F. Lewandowski, Wojciech Korfanty..., s. 100.
} 
dobre, jeżeli tylko prowadzą do celu"22. Niemniej w przywołanej biografii Korfantego nie natrafiłam na trop domniemanych afer finansowych czy gospodarczych z udziałem tego polityka. Negatywne opinie o polityku nie przerodziły się $\mathrm{w}$ czarną legendę mogącą zdyskredytować pozytywny obraz Korfantego w historii.

W Ślaskim dziękczynieniu Lewandowskiego mamy zatem do czynienia z nową wersją kontrfaktyczności. Opowiedziany odmienny od rzeczywistego fragment życiorysu, alternatywny epizod polskiej historii, nie zmienił biegu dziejów. Historia potoczyła się tak, jakby tego epizodu nie było. Tam, gdzie zawieszona jest ocena $\mathrm{w}$ kategoriach prawdy i fałszu, możliwe jest to, co prawdopodobne. Pozostaje pytanie: czy tak opowiedziana historia pozostaje jeszcze nauczycielką życia? Czy aluzyjność do znanych afer taśmowych XXI wieku powoduje, iż wątek historyczny pełni tu rolę publicystyki politycznej, a u czytelników może powstać wrażenie, że autor bardziej niż $\mathrm{w}$ roli nauczyciela myślenia historią występuje $\mathrm{w}$ roli skandalisty?

W kontekście powyższych trzech przekształceń (odkształceń?) historii $\mathrm{w}$ kryminałach retro należy zwrócić uwagę na problem niezmiernie istotny. W przypadku "historii kontrfaktycznych" tworzonych przez historyków ich adresatem jest historyk lub miłośnik historii. Porozumienie nadawcy i odbiorcy bazuje na profesjonalizmie i kompetencji historycznej obu stron. Opowiadane historie niebyłe mają z założenia przynosić intelektualne korzyści w rozumieniu dziejów. Inaczej bywa, gdy historia wkracza do obiegu popularnego, na przykład do kryminału retro, który ma - jak zostało powiedziane - dwóch różnych adresatów.

Wśród grupy typowych odbiorców kryminału retro - przypomnę - może znajdować się adresat literatury i kultury popularnej o niskich, a w każdym razie niekoniecznie wysokich kompetencjach kulturowych i o niewielkiej wiedzy historycznej. Sięga on po ten podgatunek kryminału jak po każdy inny podgatunek powieści kryminalnej, a literatura popularna jest jedynym obiegiem literackim, z którym na co dzień obcuje. Literatura stanowi dla niego rozrywkę. To ten, który niekoniecznie czyta Sienkiewicza i nie wie, kim była Zofia Kossak. Zatem cokolwiek zostanie o historii powiedziane, przyjmie z tak zwaną "dobrą wiarą" w prawdziwość prezentowanych osób i wydarzeń. Edukacyjna funkcja kryminału, ale także każdej innej odmiany literatury popularnej „traktującej o historii” może być w przypadku jego lektury nie do przecenienia.

Zupełnie inaczej rzecz się ma z wprowadzeniem na karty kryminału retro niebyłego wydarzenia, alternatywnego życiorysu znanego pisarza czy bohatera historycznego. $Z$ tego rodzaju przeformułowań zdaje sobie sprawę być może już tylko drugi typ odbiorcy kryminału, literacki erudyta i znawca historii. Ten bawić się będzie (lub nie) epizodem z alternatywnej biografii Gombrowicza. Doceni (lub nie) historyczną szaradę, jaką stanie się dla niego przepisywana historia włącznie z jej wersją sprzeczną $\mathrm{z}$ faktografią. 
Pierwsza grupa czytelników, zdecydowanie niemała w sytuacji ograniczenia szkolnej edukacji historycznej i braku kształcenia literackiej erudycji, ta grupa czytelników każdą wersję biografii, każde niebyłe wydarzenie, każdą uproszczoną ocenę historii może przyjąć jako pewnik, potraktować może jako historię autentyczną, rzeczywistą, jak źródłowo weryfikowalną historią faktograficzną. Konsekwencje takiej lektury są łatwe do przewidzenia. Wynika stąd, iż na autorze literackich historii alternatywnych bądź kontrfaktycznych wątków ciąży niebagatelna odpowiedzialność za dzieło swojej wyobraźni.

Problem pisarskiej odpowiedzialności za literacki obraz historii pojawia się nie po raz pierwszy, stawał się on już przedmiotem naukowych debat $^{23}$, ale zyskuje w XXI wieku nowy wymiar i niebagatelne znaczenie. Zamierzam do niego powrócić w zapowiedzianym wyżej tekście, tym razem poświęconym historii alternatywnej w prozie Konrada T. Lewandowskiego.

\section{B I B LIO G R A F I A}

Czubaj M., Etnolog w Mieście Grzechu. Powieść kryminalna jako świadectwo antropologiczne, Gdańsk 2010.

Dermandt A., Historia niebyła: Co by było gdyby...?, przeł. M. Skalska, Warszawa 1999.

Kula M. , Krótki raport o użytkowaniu historii, Warszawa 2004.

Lewandowski J. F., Wojciech Korfanty, Warszawa 2013.

Lewandowski K. T., Bogini z labradoru. Powieść kryminalna, Wrocław 2007.

Lewandowski K. T., Elektryczne perty. Powieść kryminalna retro, Wrocław 2007.

Lewandowski K. T., Magnetyzer. Powieść kryminalna retro, Poznań 2007.

Lewandowski K. T., Perkalowy dybuk. Powieść kryminalna retro, Wrocław 2009.

Lewandowski K. T., Rzemieślnik metafizyk, rozm. P. Dunin-Wąsowicz, [online] http://ksiazki.onet.pl/rzemneslnik-metafizyk/x078z (dostęp: 25.08.2016).

Lewandowski K. T., Śląskie dziękczynienie. Powieść kryminalna retro, Wrocław 2010.

Polityka historyczna w literaturze polskiej, red. K. Stępnik, M. Piechota, Lublin 2011.

Tierling-Śledź E., Powstanie styczniowe, którego nie było, czyli historia alternatywna w powieści Adama Przechrzty Gambit Wielopolskiego, [w:] Dyskurs powstańczy w kulturze polskiej, red D. Dąbrowska, Szczecin 2015.

Wajda K., Śladem retrozbrodni [online] http://www.dwutygodnik.com/artykul/3820-sladem-retrozbrodni.html (Dostęp: 25.08.2016).

Węcławiak T., Historia historii nierówna - kilka uwag o definicji historii alternatywnej, „Podteksty. Czasopismo kulturalno-naukowe” 2007, nr 4 [online] http://podteksty.amu.edu.pl/podteksty/?action=dynamic\&n$\mathrm{r}=11 \& d$ zial=4\&id=254 (dostęp: 05.08.2016).

${ }^{23}$ Zob. Polityka historyczna w literaturze polskiej, red. K. Stępnik, M. Piechota, Lublin 2011. 


\section{STRESZCZENIE}

Autorka artykułu wyraża przekonanie, iż na przełomie XX i XXI wieku spotykamy się ze swoistą restytucją historii w różnych odmianach i nurtach literatury, czego dowodem może być między innymi twórczość Konrada T. Lewandowskiego. Celem artykułu jest ukazanie sposobów „użytkowania historii” w kryminałach retro tego autora. Po przedstawieniu wyznaczników gatunku, badaczka śledzi obecne w powieściach Lewandowskiego różne odmiany historycznego prawdopodobieństwa, przechodzenie autora od prawdy historycznej do „historii niebyłej". Stawia też pytanie o konsekwencje takiego operowania historią dla odbiorcy prozy historycznej u progu XXI wieku.

\section{Słowa kluczowe}

kryminał retro, historia alternatywna, historia kontrfaktyczna, Konrad T. Lewandowski

\section{S U M M A RY}

\section{Marriage between crime novel and history, a few remarks on 'Retro Crime Stories' by Konrad T. Lewandowski}

The author is of the opinion that in the late $20^{\text {th }}$ and early $21^{\text {st }}$ centuries we experience a peculiar restitution of history in miscellaneous literary types and trends, one example of which could be the output by Konrad T. Lewandowski. The main purpose of the article is to present the methods of 'utilising history' in his retro crime stories. Having demonstrated the features of the genre, Tierling-Śledź goes on to trace back various types of historical probability in Lewandowski's works, his transitions from historical facts to 'unexisting history'. She also poses a question about the consequences of handling history in such a fashion for the reader of historical prose in the early $21^{\text {st }}$ century.

\section{Keywords}

retro crime story, alternative history, counterfactual history, Konrad T. Lewandowski 